\title{
Influence of Counselling Services on Perceived Academic Performance of Secondary School Students in Lagos State
}

\section{Foluke Nike Bolu-Steve}

Department of Counsellor Education, Faculty of Education, University of Ilorin, Ilorin Kwara State, Nigeria, bolu-steve.fn@unilorin.edu.ng

\section{Oluwabunmi Olayinka Oredugba}

Department of Counsellor Education, Faculty of Education, University of Ilorin, Ilorin Kwara State, Nigeria

This study aimed at looking at the influence of counseling services on perceived academic performance of secondary school students in Lagos State. At the first stage, the researchers purposively selected Ikorodu L.G.A in Lagos State. At the researchers selected two schools (1 Private schools, \& 1 Public schools), using simple random technique. Thus, a total of two schools were picked in each of the L.G.A. Finally, simple random sampling was used in selecting eighty students in each L.G.A, thus making a total of two hundred and forty Senior Secondary students that participated in the study. Six hypotheses were generated for the purpose of this study. Data were gathered using a researcher designed instrument tagged "Influence of Counselling Service on Academic Performance of Students Questionnaire (ICAPSQ). The findings of this study showed that there was no significant difference on the basis of age, class level and school type. However a significant difference was found on the basis of respondent's religion, gender and the number of times the students visited the counselor. It was therefore recommended that the ministry of education should ensure that guidance and counselling units are established in all public and private secondary schools in Nigeria.

Key Words: influence, counselling service, academic performance, students, secondary school

\section{INTRODUCTION}

Counselling is a special kind of relationship that involves an interaction between the client and the counsellor. The counsellors tries to use their professional training, skills, expertise and experience to help the client to overcome an area of conflict or block which hitherto has hindered the inter and intra-personal relationships growth and

Citation: Bolu-Steve, F. N. \& Oredugba, O. O. (2017). Influence of Counselling Services on Perceived Academic Performance of Secondary School Students in Lagos State. International Journal of Instruction, 10(2), 211-228. https://doi.org/10.12973/iji.2017.10214a 
development (Umoh, 2004). Counselling is an helping relationship where a person is assisted in a face-to-face interaction. Counselling programmes are designed to assist clients who have challenges. The goals of counselling are broadly based on behavioural change, problem resolution and symptom removal. Amekudi (2004) defined counselling as a process of helping an individual to understand their world in order to utilize their potential. According to Oye, Obi, Mohd and Bernice (2012) counselling programmes provide opportunities for students to improve themselves, relate well and develop ethical standards for educational pursuit. It also helps the school child to obtain holistic educational development. The counselor is strategically placed in schools in order to assist the students. The National Policy on Education (1998) specifically mentioned the need for counselling programmes in school. According to Adegoke (2004) the counsellor can assist in- school adolescents to handle behavioural, educational and psychological problems. Alabi (2006) noted that this process creates a change in personality organization and structure which are relatively permanent.

The place of counselling programmes in schools cannot be overemphasized especially with the daily expansion in the enrolment of students in schools, growing needs of youths in Nigeria, the continual unrest in schools and the repeated changes in the educational system (Idowu,2004). Counselling services has become an essential programme in schools and this cannot be done in isolation. There is the need for the counsellor to develop good relationship with other school personnel. Onanuga (1993) emphasized on the need to incorporate guidance and counselling programmes into Nigeria educational system. In the same vein, Nwachukwu (2007) noted that if the 6-33-4 educational system must succeed, then the place of guidance and counselling services should not be overlooked.

There are two major types of counselling, they are individual counselling (face to face interaction between the professional counsellor and the client) and group counselling (this between the professional counsellor and clients who have similar concern) (Omotosho, 2000). The major counselling services/ programmes in schools include:

Information Service. The school guidance counsellor provides the students with accurate information on educational, vocational and personal social opportunities facts that are available in order to assist the students in making informed decision and choices (Alabi, 2006).

Orientation Service. This entails acquainting new students with the academic environment. The school is usually new to the students. An orientation activity helps the students to adjust to the new environment. At this point, students are exposed to the rules and regulation guiding behavior and interpersonal relationship within the school (Idowu, 2004).

Placement Service. This involves placing students in an appropriate class or school, courses, training or vocations. The counselor assist the students to choose the right subject combination in line with their traits. This process is useful in carrying out the placement of these students into science, arts, commercial or technical class. The 
placement programmes also assist the graduating students to choose the right course at the University (Alabi, 2006).

Appraisal service. Adefila (2000) noted that the appraisal of an individual is the value judgment arrived at, based on the result of the assessment of various relevant characteristics of the person. It involves the collection of data, analysis of subjective and objective personal and psychological data about a student. This gives a full understanding of these students and how they can be helped.

Counselling Service. This is a face to face interaction between the counsellor and the client who has a challenge. Counselling in schools is aimed at assisting the students to live a more productive life and self-satisfying life style. The main focus of the school counselor is to facilitate needed educational growth among the students (Oguntuga, 2015).

Follow-up Service. It consists of activities which helps the counsellor to access if the client is coping after the counselling session. This could involve visit to other places like institutions and employment establishment. Follow up services is necessary for planning and evaluation purpose (Adeoye, 2016).

Evaluation Service. This helps in assessing the effectiveness of the school counselling programmes. Data gathered from the evaluation process, enable the counsellor to improve, modify or suspend any service in the programme (Yusuf, 2004).

Referral Service. This is the transferring a client to another professional counsellor or agency where their problem can be appropriately handled. These services are the fundamental basis of counselling programmes (Idowu, 2004).

All these services aimed at improving the academic standard of secondary school students. Counselling services has a lot of impact on students' academic performance. Counsellors play active roles in dealing with the emotional and psychological problems that could mar the academic progress of the students. Modo, Sanni, Umah and Mogbo (2013) noted that students who are exposed to educational guidance and counselling services perform in their study better than their counterparts. Omotosho (2004) explained that the counselor helps to guide the students in the choice of career that matches with their personality. In the same vein, Egbule (2006) emphasized that educational guidance and counselling services enable students to make appropriate use of their educational opportunities. It aids in planning effective study habit which in turn, enhances students' academic competencies. Furthermore, Adeoye (2016) revealed that counselling services are intervention process that are effective in dealing with student academic problems and at the same time foster healthy heterosexual relationship among the students. The counsellor also keeps proper record of continuous assessment of the academic activities of the students. Through the counsellors effort, the academic deficiencies ranging from slow learning, lack of attention, poor concentration and other learning difficulties are remedied (Yusuf, 2004).

Several research works have been done to improve counselling practice in different countries. In the United States, counsellors are expected to be licensed in order to 
practice counselling profession. This is important because counsellors are involved in a profession that deals with human subjects (Mulhauser,2016). From recent reports, counsellors worldwide are focusing more on the promotion of mental health. In the same vein, Sreedhar (2001) noted that the cultural heritage of the India's is closely related to modern techniques of counselling. The researcher therefore recommended eclectic approach style of counselling and that each counsellor should develop their own style of dealing with clients instead of using the old conventional techniques of counselling. In the United States, the school counselling program began as a guidance movement and Mulhauser (2016) explained that counselling services has become an integral part of the educational system. These program has helped many students in adjusting to social, emotional and academic challenges. In Japan, the major aim of guidance program is to provide services that will assist students to develop their abilities and facilitate selfunderstanding (Gatua,2012).

\section{Statement of Problem}

In school's success is measured by the level of the students' academic performance. Student's performance remains a top priority for educators. Stalk holders in education has affirmed that the goal of education cannot be achieved without the input of professional counsellors. Counselling programmes plays a vital role in preventing educational, personal, social, mental and emotional problems. Many school's administrators are yet to embrace the programme because they do not see the benefit of appropriate counselling services. There is a continuous role conflict between the principals, teachers and the school counsellors and this threaten the stability of guidance programmes in schools (Attarl, 1999). Adegoke (2004) affirmed that students encounter a lot of academic challenges which they find difficult to cope with. Oluwatimilehin (2012) explained that indiscipline, drug addiction, poverty, non- challant attitude of the students have resulted into poor academic performance. As such, students need the services of professional counsellor in school. In the study area effective counselling services are not available or nonexistence in some schools. In places where these services are available the number of clients attending counselling sessions are dismally low. Also, some principals still prefer to use career masters rather than professional counsellors for guidance services. The new and advance professional academic problem-solving techniques can only be delivered by qualified professionals.

Ndiranju (2007) worked on the influence of guidance and counselling programme on academic performance of some selected secondary school student in Nakuru district in Egerton, Carey and Harrington (2010) carried out a research on the impact of counselling on student educational outcomes in high schools while Fakorede (2014) worked on the influence of school counsellor on career choice of senior secondary school students in Ilorin Metropolis. These researchers emphasized on the need to enforce guidance programmes in schools. Owing to the gap identified above, the current researchers have tried in this study to look at the influence of the counselling programmes on secondary school student's academic performance. 


\section{Purpose of the Study}

The purpose of this study is to investigate on the influence of counselling services on secondary school students' perceived academic performance in Lagos State. It was also meant to find out if such perception is a function of age, religion, gender, class level and school type.

\section{Research Questions}

The following research questions were generated for this study:

1. What is the influence of counselling services on perceived academic performance as expressed by secondary school students in Lagos State?

2. Is there any significant difference in the influence of counselling services on secondary school students 'perceived academic performance in Lagos State based on age?

3. Is there any significant difference in the influence of counselling services on secondary school students 'perceived academic performance in Lagos State based on religion?

4. Is there any significant difference in the influence of counselling services on secondary school students' perceived academic performance in Lagos State based on gender?

5. Is there any significant difference in the influence of counselling services on secondary school students' perceived academic performance in Lagos State based on class level?

6. Is there any significant difference in the influence of counselling services on secondary school students' perceived academic performance in Lagos State based on school type?

\section{Research Hypotheses}

In order to provide answers to the problems raised in this study, the following null hypotheses are formulated;

1.There is no significant difference on the influence of counselling services on secondary school students' perceived academic performance in Lagos State based on age.

2. There is no significant difference on the influence of counselling services on secondary school students perceived academic performance in Lagos State based on religion.

3.There is no significant difference on the influence of counselling services on secondary school students' perceived academic performance in Lagos State based on gender. 
4.There is no significant difference on the influence of counselling services on secondary school students' perceived academic performance in Lagos State based on class level.

5.There is no significant difference in the influence of counselling services on secondary school students' perceived academic performance in Lagos State based on school type.

\section{METHOD}

Descriptive survey design was used in this study. Stangor (2004) described descriptive survey as a systematic description of an event in a very factual and precise manner. This method provides accurate description of a particular phenomenon at one or more points. The survey approach is considered appropriate since the study is interested in gathering information from a representative sample of secondary school students in Lagos State.

Participants The study was carried out using a multi-stage sampling technique. The researchers purposively selected Ikorodu L.G.A in Lagos State. This is because the L.G.A is large. All the three L.G.As in Ikorodu L.G.A (Ikorodu West, Ikorodu Central and Igbogbo Bayeku) were used for this study. At stage two, the researchers selected two schools (1 Private schools, \& 1 Public schools), using simple random technique. Thus, a total of two schools were picked in each of the L.G.A. The senior secondary school students were also purposively selected, this is because these group students have been in school for some considerably number of years and they must have interacted with the school counsellor. Finally, simple random sampling was used in selecting eighty students in each L.G.A ( 40 from private schools \& 40 from public schools). Thus making a total of two hundred and forty SSS students participated in the study. According to Abiri (2007) simple random technique is a method of selection in which every member of the population has equal chance of being selected.

\section{Data Collection Tool(s)}

Data were gathered through the administration of an instrument titled "Influence of Counselling programme on Academic Performance of Students Questionnaire" (ICAPSQ). The psychometric property of the instrument was established by the researchers. The questionnaire was divided into two sections. Section A contained the demographic data. Section B, was designed to elicit information on the influence of counselling programme on academic performance. The Four-Point Likert Type scale was adopted for use in Section B as follows; Strongly Agree (SA) 4 points, Agree (A) 3points, Disagree (D) 2 points and Strongly Disagree (SD) 1 point.The t-test and ANOVA statistics were used to test the hypotheses at 0.05 alpha level of significance. 


\section{FINDINGS}

Table 1

Distribution of Respondents

\begin{tabular}{|c|c|c|}
\hline Variables & Frequency & Percentage (\%) \\
\hline \multicolumn{3}{|l|}{ Age } \\
\hline 12-14years & 171 & 71.2 \\
\hline $15-17$ years & 67 & 27.9 \\
\hline $18-20$ years & 2 & 0.8 \\
\hline Total & 240 & 100 \\
\hline \multicolumn{3}{|l|}{ Sex } \\
\hline Male & 91 & 37.9 \\
\hline Female & 149 & 62.1 \\
\hline Total & 240 & 100 \\
\hline \multicolumn{3}{|l|}{ Class level } \\
\hline SSS1 & 135 & 56.2 \\
\hline SSS2 & 74 & 30.8 \\
\hline SSS3 & 31 & 12.9 \\
\hline Total & 240 & 100 \\
\hline \multicolumn{3}{|l|}{ Religion } \\
\hline African Traditional & 24 & 10.0 \\
\hline Religion & & \\
\hline Christianity & 144 & 60.0 \\
\hline Islam & 72 & 30.0 \\
\hline Total & 240 & 100 \\
\hline \multicolumn{3}{|l|}{ School } \\
\hline Private & 120 & 50.0 \\
\hline Public & 120 & 50.0 \\
\hline \multicolumn{3}{|l|}{ Consulting the counselor } \\
\hline Never & 70 & 29.2 \\
\hline 1-2 times & 98 & 40.8 \\
\hline 3-4 times & 24 & 10.0 \\
\hline 5times and above & 48 & 20.0 \\
\hline Total & 240 & \\
\hline
\end{tabular}

Table 1 shows that $171(71 \%)$ of the respondents are within the range of 12-14 years, 67 of them are between 15-19 years of age. 91 (37.9\%) of them are males while 149 $(62.1 \%)$ are females. The number of senior secondary school students in year one that participated in the study are 135 (56.2), those in SSS 2 and 3 are 74(30.8) and 31 (12.9) respectively. Respondents from the three major religion also participated in the study. The table also shows the number of times the students consulted with the counselor, 70(29.2) of them have never visited the counselor, 98(40.8) had consulted with the counselor about one or two times while $48(20 \%)$ of the respondent has gone to sees the counselor more than 5 times.

Research Question 1: What is the influence of counselling services on perceived academic performance of secondary school students Ikorodu LGA of Lagos 
Table 2

Mean and rank order of counselling service on students 'perceived academic performance

\begin{tabular}{clll}
\hline $\begin{array}{c}\text { Item } \\
\text { No }\end{array}$ & $\begin{array}{l}\text { In my own opinion counselling programmes in my school has helped } \\
\text { me to }\end{array}$ & Mean & Ranking \\
\hline 3 & cope with my academic task & 3.22 & $1^{\text {st }}$ \\
\hline 17 & make adequate preparation for my exams & 3.21 & $2^{\text {nd }}$ \\
\hline 13 & $\begin{array}{l}\text { develop and maintain good interpersonal relationship that enhances } \\
\text { my academic pursuit }\end{array}$ & 3.19 & $3^{\text {rd }}$ \\
\hline 20 & avoid behavior that can mar good academic performance & 3.17 & $4^{\text {th }}$ \\
\hline 7 & daily enhance my academic programme & 3.16 & $5^{\text {th }}$ \\
\hline 6 & identify my potentials & 3.16 & $5^{\text {th }}$ \\
\hline 9 & identify various tips in enhancing our my assimilation rate. & 3.15 & $7^{\text {th }}$ \\
\hline 19 & manage my time & 3.14 & $8^{\text {th }}$ \\
\hline 2 & $\begin{array}{l}\text { use various study method techniques } \text { I learnt during group } \\
\text { counselling. }\end{array}$ & 3.11 & $9^{\text {th }}$ \\
\hline 5 & develop self-motivation technique for positive academic performance & 3.07 & $10^{\text {th }}$ \\
\hline 8 & handle some personal challenges that can affect my academics & 3.06 & $11^{\text {th }}$ \\
\hline 4 & be academically stable & 2.99 & $12^{\text {th }}$ \\
\hline 18 & deal with examination phobia & 2.97 & $13^{\text {th }}$ \\
\hline 1 & handle various educational challenges & 2.97 & $13^{\text {th }}$ \\
\hline 15 & skillfully handle the major core subjects where I have challenges & 2.95 & $15^{\text {th }}$ \\
\hline 10 & improve my study habit & 2.90 & $16^{\text {th }}$ \\
\hline 16 & use the computer to promptly do my home assignment & 2.80 & $17^{\text {th }}$ \\
\hline 12 & develop interest in the subject l dislike & 2.78 & $18^{\text {th }}$ \\
\hline 14 & handle group class assignment & 2.75 & $19^{\text {th }}$ \\
\hline 11 & $\begin{array}{l}\text { deal with my family problem in order not to lose concentration on my } \\
\text { academic pursuit }\end{array}$ & 2.09 & $20^{\text {th }}$ \\
\hline
\end{tabular}

Table2 shows the mean and the ranking of the items responded to by the respondents. The item 3 was ranked $1^{\text {st }}$ with the mean score of 3.22 and it states that in my own opinion counselling programmes in my school has helped me to cope with my academic task. Item 17 was ranked $2^{\text {nd }}$ with the mean score of 3.21 , and it states that, in my own opinion counselling programmes in my school has helped me to make adequate preparation for my exams, while item 13 was ranked $3^{\text {rd }}$ with the mean score of 3.19. However, item 11 was ranked $20^{\text {th }}$ with the mean score of 2.09 . All the items were ranked above 2.50 and only item 11 was below 2.50 . This shows that all the respondents agreed on the influence of counselling services on perceived academic performance of senior secondary school.

Table 3

Influence of Counselling Services on perceived Academic Performance of Secondary school students in Lagos

\begin{tabular}{llll}
\hline Impact & Frequency & Percentage (\%) & Mean \\
\hline Low & 77 & 32.1 & 40.03 \\
\hline High & 163 & 67.9 & 65.90 \\
\hline
\end{tabular}

Table 3 indicates the influence of counselling services of secondary school students in Ikoeodu LGA of Lagos State. 77 (32.1\%) of the respondents stated that counselling 
services had low impacts on their academic performance while $163(67.9 \%)$ of the respondents stated that counselling services had high impact on their academic performance. For any respondents the lowest possible score is 20 (i.e. 1 x $20=20$ ) while the highest possible score was 80 (i.e. 4 × $20=80$ ). The range is 60 (i.e 80 $20=60$ ). Therefore, the mid-point is 30 (i.e 60/2). Hence the cut-off point for deciding whether a mean value is low or high is either $20+30$ or $80-30$, which in either case comes to 50 As such, any mean score of 50 or higher is high while a mean score of less than 50 is low.

Hypothesis One: $\quad$ There is no significant difference in the influence of counselling services onperceived academic performance of secondary school students in Lagos on the basis of age.

Table 4

Analysis of Variance (ANOVA) on the Influence of Counselling Services on Secondary School Students Perceived Academic Performance on the Basis of Age

\begin{tabular}{llllllll}
\hline Source & $d f$ & $S S$ & $\begin{array}{l}\text { Mean } \\
\text { Squares }\end{array}$ & $\begin{array}{l}\text { Cal. } \\
\text { ratio }\end{array}$ & F- & Crit. F-ratio & P-value \\
\hline Between Group & 2 & 15.758 & 7.879 & 0.78 & 3.00 & .925 \\
\hline Within Group & 237 & 23842.904 & 100.603 & & & \\
\hline Total & 239 & 23858.662 & & & & \\
\hline
\end{tabular}

Table 4 indicates that the calculated F-ratio of 0.78 is less than the critical F-ratio of 3.00 and calculated p-value is greater than 0.05 alpha level of significance. Based on this result, it was concluded that there is no significant difference in the influence of counselling services on perceived academic performance of secondary school students in Lagos on the basis of age. The hypothesis was therefore accepted.

Hypothesis Two: There is no significant difference in the influence of counselling services on perceived academic performance of secondary school students in Lagos on the basis of religion.

Table 5

Analysis of Variance (ANOVA) on the Influence of Counselling Services on perceived Academic Performance Secondary School Students on the Basis of Religion

\begin{tabular}{lllllll}
\hline Source & $d f$ & SS & $\begin{array}{l}\text { Mean } \\
\text { Squares }\end{array}$ & $\begin{array}{l}\text { Cal. F- } \\
\text { ratio }\end{array}$ & Crit. F-ratio & P-value \\
\hline Between Group & 2 & 769.621 & 384.810 & $* 3.95$ & 3.00 & .021 \\
\hline Within Group & 237 & 23089.042 & 97.422 & & & \\
\hline Total & 239 & 23858.662 & & & &
\end{tabular}

Significant, $\mathrm{p}<0.05$ alpha level

Table 5 indicated that the calculated F-ratio of 3.95 is greater than the critical F-ratio of 3.00 and calculated p-value of .021 is less than 0.05 alpha level of significance. As a result of this value, it was concluded that there is significant difference on the influence of counselling services on perceived academic performance of secondary school students in Lagos on the basis of religion. The hypothesis was therefore rejected. In 
order to able to establish both the magnitude and direction of the differences in this variable, a post-hoc test - Duncan Multiple Range Test (DMTR) was conducted.

Table 6

DMRT comparing the mean of Influence of Counselling Services on perceived Academic Performance of Secondary School Students on the Basis of Religion

\begin{tabular}{lclll}
\hline Duncan Groupings & $N$ & Means & Group & Years \\
\hline A & 24 & 63.41 & 1 & ATR \\
\hline B & 72 & 61.43 & 2 & Islam \\
\hline C & 144 & 58.44 & 3 & Christianity \\
\hline
\end{tabular}

Table 5 showed the DMRT comparing the differences in the impact of counselling services on student academic performance. Group 1 with a mean score of 63.41 differ significantly from Groups 2 and 3 with mean scores of 61.43 and 58.44 respectively. Equally, group 3 with a mean score of 58.44 significantly differ from other groups, hence group 1 and 3 are responsible for the difference found in ANOVA used to test hypothesis 5 .

Hypothesis Three: There is no significant difference in the influence of counselling services on perceived academic performance of secondary school students Lagos on the basis of gender.

Table 7

Mean, Standard Deviation and t-test of the Respondents' on Influence of Counselling Services on perceived Academic Performance Secondary School Students on the Basis of Gender

\begin{tabular}{lrclllcl}
\hline Gender & $N$ & Mean & $S D$ & $D f$ & Cal. $t$-value & Crit. $t$-value & $P$-value \\
\cline { 1 - 4 } Male & 91 & 62.05 & 8.67 & 238 & $* 2.72$ & 1.96 & 0.046
\end{tabular}

Significant, $\mathrm{p}<0.05$ alpha level

Table 7 indicates that the calculated t-value of 2.72 is greater than the critical t-value of 1.96 and calculated p-value is less than 0.05 alpha level of significance. Since calculated p-value is less than alpha level therefore, the null hypothesis is rejected. Hence there is significant difference in the influence of counselling services on perceived academic performance of secondary school students in Lagos on the basis of gender.

Hypothesis Four: There is no significant difference in the influence of counselling services on students perceived academic performance of secondary school students in Lagos on the

Table 8 basis of class level.

Analysis of Variance (ANOVA) on the Influence of Counselling Services on Perceived Academic Performance of Secondary School Students on the Basis of Class Level

\begin{tabular}{llllcll}
\hline Source & $d f$ & SS & Mean Squares Cal. F-ratio & Crit. F-ratio & P-value \\
\hline Between Group & 2 & 502.289 & 251.144 & 2.54 & 3.00 & .080 \\
\hline Within Group & 237 & 23356.374 & 98.550 & & & \\
\hline Total & 239 & 23858.662 & & & & \\
\hline
\end{tabular}


Table 8 shows a calculated F-ratio of 2.54 less than critical F-ratio of 3.00 and calculated p-value greater than 0.05 alpha level of significance. Since the calculated pvalue is greater than alpha level, the hypothesis is therefore accepted. Hence, there is no significant difference in the influence of counselling services on perceived academic performance of secondary school students in Lagos on the basis of class level.

Hypothesis Five: There is no significant difference in the influence of counselling services on perceived academic performance of secondary school students in Lagos on the basis of school

Table 9

Mean, Standard Deviation and t-test of the Respondents' on Influence of Counselling Services on perceived Academic Performance of Secondary School Students on the Basis of School

\begin{tabular}{|c|c|c|c|c|c|c|c|}
\hline School & $N$ & Mean & $S D$ & $D f$ & Cal. $t$-value & Crit. $t$-value & $P$-value \\
\hline Private & 120 & 59.98 & 10.67 & & & & \\
\hline & & & & 238 & 0.21 & 1.96 & 0.19 \\
\hline Public & 120 & 59.70 & 9.32 & & & & \\
\hline
\end{tabular}

Table 9 indicates that the calculated t-value of 0.21 is greater than the critical t-value of 1.96 and calculated p-value is greater than 0.05 alpha level of significance. Since calculated p-value is greater than alpha level therefore, the null hypothesis is accepted. Hence there is no significant difference in the influence of counselling services on perceived academic performance of secondary school students in Lagos on the basis of school.

Hypothesis Six: $\quad$ There is no significant difference in the influence of counselling services on perceived academic performance of secondary school students in Lagos on the basis of number of times they visited the school counsellor for counselling

Table 10

Analysis of Variance (ANOVA) on the Influence of Counselling Services on perceived Academic Performance of Secondary School Students on the Basis of number of times they visited the school counsellor for counselling

\begin{tabular}{|c|c|c|c|c|c|c|}
\hline Source & $d f$ & $S S$ & Mean Squares & Cal. F-ratio & Crit. F-ratio & $P$-value \\
\hline Between Group & 3 & 5460.977 & 1820.326 & $* 23.35$ & 3.00 & 0.00 \\
\hline Within Group & 236 & 18397.666 & 77.956 & & & \\
\hline Total & 239 & 23858.663 & & & & \\
\hline
\end{tabular}

Table 10 shows that the calculated F-ratio of 23.35 is greater than the critical F-ratio of 3.00 and calculated p-value is less than 0.05 alpha level of significance. Since the calculated p-value is less than alpha level, the hypothesis is rejected. Hence, there is no significant difference in the influence of counselling services on perceived academic performance of secondary school students in Lagos on the basis on number of times they visited the school counsellor. In order to able to establish both the magnitude and direction of the differences in this variable, a post-hoc test - Duncan Multiple Range Test (DMTR) was conducted. 
Table 11

DMRT comparing the mean of Influence of Counselling Services onperceived Academic Performance of Secondary School Students on the Basis on Number of Times They Visited the School Counsellor

\begin{tabular}{lllll}
\hline Duncan Groupings & $N$ & Means & Group & No of Visitation \\
\hline A & 48 & 63.35 & 1 & 5 times and above \\
\hline B & 24 & 62.92 & 2 & 3 or 4 times \\
\hline B & 98 & 62.66 & 3 & 1 or 2 times \\
\hline C & 70 & 52.41 & 4 & Never \\
\hline
\end{tabular}

Table 11 showed that group one with a mean score of 63.35 differs significantly from groups two, three and four with the mean scores of 62.92, 62.66 and 52.41 respectively. All groups differed from one another significantly but significant difference was as a result of respondents who visited counsellor 5 times and above, therefore, the hypothesis cannot be accepted.

\section{DISCUSSION}

Most the respondents agreed that counselling services in school has influenced their perceived academic performance. Makinde (1994) emphasized that the role of school counsellors cannot be overemphasized in schools. Counsellors help to foster career management strategies by assisting the students to effectively develop their skills. Egbule (2006) attested to the fact that schools that has functional counselling programmes will definitely make positive impact on students' academic progress.

Respondents view did not differ on the basis of age. This might be due to the fact that most of these students have visited the counselling center at one time or the other and they have benefited from the counselling services provided by the school counsellor. This study also corroborates the view of Ajiteru (2013) who also discovered that both students and teachers of different age groups have similar perception on the positive influence of counselling services on students academics.

The religious belief of these students influenced their perception. Bolu-Steve, Olawuyi and Shaba (2015) stated that the level of religiosity has a way of influencing ones decision. Irrespective of the religious background of the students, Oye, Obi, Mohd and Bernice (2012) confirmed that school counselling programmes assist students in dealing with emotional, social and academic issues.

Male and female respondents differ in their opinion on the impact of counselling services on secondary school student's perceived academic performance of secondary school students. Aluede, Oyaziwo, Imhonde, Henry, Eguavoen, Agatha (2006) revealed that there is gender differences in counselling needs of students. They revealed that the reasons why male and female students visit the school counselor are different. This could account for the differences in their opinion. However, Onyejiaku (1991) asserted that despite the differences in gender, student's attitude to counselling services are favorable. 
The class level and the type of school of the respondents notwithstanding, they all have similar view on the influence of counselling services on respondent's academic performance. Arhedo, Adomeh and Alude (2009) vividly emphasized on the role of the school counsellor in the implementation of universal basic education at all levels. In the same vein, Carey and Harrington (2010) noted that counselling services assist students at all levels to become fully acquainted with occupational and educational opportunities that is at their disposal. The services of the counsellors are also needed when student are transiting from junior to senior class level in the secondary school (Adeoye , 2016). On the number of times the respondents have consulted or visited the counsellor differ as shown on the table. Tambawal (2011) stressed that counselling programme is an integral part of the school system and those who consult the school counsellor often are better adjusted academically. They also affirmed that such students finds their way around complicated curriculum and this in turn enhances their academic performance.

\section{CONCLUSION}

The study revealed that there was no significant difference in the impact of counselling service on students' perceived academic performance on the basis age, gender, class level and school type. However, a significant difference was found on the basis of religion and number of times the student had visited the counselor. Secondary school counsellors are professional educators with mental health perspective. They are equipped to handle the various challenges confronting in school adolescents. As such, school counsellors must strive to create and devote enough time for students who need assistance. It was therefore recommended that the Ministry of Education in each state should enforce the establishment of counselling centers in both public and private secondary schools. The principals should employ professional counsellors and discard the use of career masters in schools. This is because counsellors are trained as psychologist and human relation expert. The school administrators should give necessary support to the counsellor by creating awareness on the importance of guidance and counselling programmes in the school.

\section{REFERENCES}

Adana, B.S. (2008). Statistical methods for students: A de-mystifying approach. Ilorin: Unilorin Press.

Adefila, A.O. (2000). Guidance needs of secondary school students as perceived by the teachers and students of Isin Local Government Area of Kwara State. Unpublished B.Ed project in the Department of Counsellor education University of Ilorin.

Adegoke, A.A. (2006). Problems and prospects of integrating cultural resources into counselling in Africa: Implication for a multi-cultural approach. Ilorin Journal of Education, 10, 26-31.

Adeoye, E.A. (2016). Relationship between the counsellor and other school guidance personnel. In A.I. Idowu (Ed.). Guidance and counselling in education, Ilorin: University of Ilorin Press. 
Ajiteru, O.M. (2013). Perceptions of teachers and students in Ilorin Metropolis towards counselling profession (Unpublished B.Ed thesis), University of Ilorin.

Alabi, L. (2006). Attitude of secondary school students towards guidance and counselling programmes in Moro Local Government Area of Kwara State. Unpublished B.Ed project in the Department of Counsellor Education University of Ilorin.

Aluede. O, Imhonde. H, \& Eguavoen. A (2006). Academic, career and personal needs of Nigerian University students. Retrieved from http://www.freepatentsonline.com/article/JournalInstructioPsychology/144014460.ht ml.

Arehedo, P.A., Adomeh, I.O.C \& Aluede. O.(2009). School counsellors role in the implementation of Universal Basic Education scheme in Nigeria. Edo Journal of Counselling 2 (1), 58-65.

Attarl, Y, (1996). A comparison of counsellor function as perceived by vocational teachers and counsellors in comprehensive high schools in Indiana. Dissertation Abstract International 39 (9), 48-52.

Bolu-Steve, F.N, Olawuyi, B.O \& Shaba, R.M. (2015). Child rearing and career performance of working class mothers in Nigeria. African Journal of CrossCultural Psychology and Sport facilitation, 17.

Carey, J.C \& Harrington, K.M. (2010). The impact of counselling on students educational outcomes in high schools. Retrieved from http:/www.umass.edu

Egbule, J.F. (2006). Guidance services. In Okobiah and Okorodudu (2006). Issues, concepts, theories and techniques of guidance and counselling. Benin city Nigeria: Ethiope publishing Cooperation..

Fakorede, A.S. (2014). Influence of school counsellor on career choice of senior secondary students in Ilorin metropolis. Unpublished B.Ed project in the Department of Counsellor Education University of Ilorin.

Gauta, D.M. (2012). Impact of guidance and counselling service on students social and emotional adjustment in public urban and rural secondary schools in Nakuru and Uasin Gishu countries, Kenya. International Journal of science and research (IJSR) ISSN(online),2319-7064

Idowu, A.I. (2004). Guidance and counselling: An overview. In A.I. Idowu (Ed.) Guidance and counselling in education, Ilorin: INDEMAC Publishers.

Kolo, A.I. (1992). Guidance services in schools: An outline for school counsellor. Lagos: Text and Leisure Publication.

Makinde, O. (1994). Fundamental of guidance and counselling. London: Macmillan Publishing Ltd.

Mulhauser, G. (2016). Professional licensing in mental health. Retrieved from counsellingresource.com 
Nwachukwu, E.O. (2007). Effects of career games and personality trait on career maturity among secondary school adolescents (Unpublished seminar paper). University of Benin, Benin.

Oguntuga, H.A. (2015). Counselling needs of student's patient attending University of Ilorin health services centre (Unpublished B.Ed project). University of Ilorin.

Oluwatimilehin, J.T.B \& Owoyele, J.W. (2012). Study habit and academic achievement in core subjects among Junior secondary school students in Ondo State, Nigeria. Bulgarian Journal of Science and Educational Policy (BJSEP), 6 (1), 155-169.

Omotosho, J.O. (2000). Counselling in Nigerian elementary schools. Journal of African Studies, 1 (1), 4-9.

Onanuga, A.C. (1993). Guidance and counselling needs in Uba, A, (Ed. (1993). Introduction to counselling: A book of readings. Ile-ife, University press.

Onyejiaku, A.B. (1991). Inevitable of school counsellors. A paper presented at CAN Workshop. Ota: June 18th.

Stangor, C.O. (2004). Research methods for behavioural sciences. Boston Houghton Mifflin Co.

Sreedhar, K.P (2001). Current trends in the practice of counselling. Retrieved from psychology4all.com

Tambuwah, M.U. (2010). Organizing and administering guidance and counselling programme at elementary schools level for effective performance. A paper delivered at a 4 day workshop for para-counselling officers by the SUBEB in collaboration with SSCOE, Sokoto.

Umoh, S.H. (2004). The need for guidance and counselling. Guidance and counselling in education. Ilorin: Indemac Publishers Ltd.

Yusuf, A.A. (2004). Teachers and pupils attitude towards the introduction of guidance services in Ilorin West primary schools (Unpublished B.Ed project). University of Ilorin. 


\section{Turkish Abstract \\ Lagos Eyaletindeki Ortaokul Öğrencilerinin Akademik Algı Performanslarında Rehberlik Servislerinin Etkililiği}

Bu çalışma Lagos Eyaletindeki ortaokul öğrencilerinin akademik algı performanslarında rehberlik servislerinin etkililğini araştırmayı amaçlamıştır. İlk aşamada, araştırmacılar Lagos Eyaletinde amaçlı örnekleme ile seçim yapmışlardır. İkinci aşamada, araştırmacılar basit rastgele seçimle iki okul seçmişlerdir (1 özel okul ve 1 devlet okulu). Böylece L.G.A'(La Guardia) nın her bir bölgesinden toplam iki okul seçilmiştir. Sonuç olarak LGA'nın her bir bölgesinden toplamda çalışmaya katılan 240 ortaokul birinci sınıf öğrencisinden basit rastgele örnekleme ile 80 öğrenci seçilmiştir. Bu çalışma için 6 hipotez geliştirilmiştir. Veriler araştırmacı tarafindan geliştirilen "Öğrencilerin Akademik Performanslarında Rehberlik Servislerinin Etkililı̆ıi Anketi" (ICAPSQ) ile toplanmıştır. Çalışmanın bulguları, yaş, sınıf seviyesi ve okul tipinin rehberlik servislerinin etkililği konusunda anlamlı bir farklılık oluşturmadığını göstermiştir.

Anahtar Kelimeler: etkililik, rehberlik servisi, akadamik performans, öğrenciler, ortaokul

\section{French Abstract \\ Influence de Conseiller Services de Performance Universitaire Perçue d'Étudiants de Collège d'enseignement général dans État de Lagos}

Cette étude a visé à regarder l'influence de conseiller des services de la performance(prestation) universitaire perçue d'étudiants de collège d'enseignement général dans l'État de Lagos. À la première étape(scène), les chercheurs ont résoluement choisi Ikorodu L.G.A dans l'État de Lagos. À l'étape(à la scène) deux, les chercheurs ont choisi deux écoles (1 écoles Privées et 1 écoles Publiques), utilisant la technique aléatoire simple. Ainsi, un total de deux écoles a été choisi(cueilli) dans chacun du L.G.A. Finalement, l'échantillonnage aléatoire simple a été utilisé dans la sélection de quatre-vingts étudiants dans chaque L.G.A, ainsi la fabrication d'un total de deux cent quarante étudiants Secondaires Seniors qui ont participé à l'étude. Six hypothèses ont été produites pour le but de cette étude. Les données ont été rassemblées utilisant un chercheur l'instrument conçu étiqueté "l'Influence de Conseiller le Service sur la Performance(Prestation) Universitaire de Questionnaire d'Étudiants (ICAPSQ). Les découvertes de cette étude ont montré qu'il n'y avait aucune différence significative sur la base de l'âge, le niveau de classe et le type scolaire.

Mots Clés: influence, conseillant service, performance universitaire, étudiants, collège d'enseignement général

\footnotetext{
Arabic Abstract$$
\text { تأثير خدمات الاستشارة على الأداء الأكاديمي ينظر من طلاب المدارس الثانوية في ولاية لاغوس }
$$

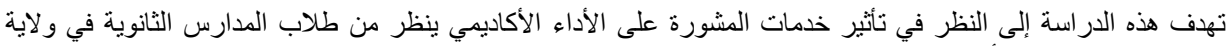

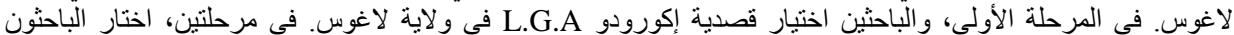

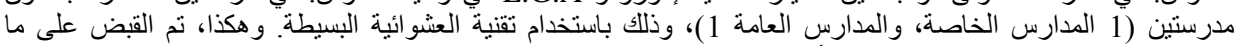

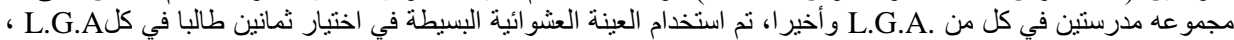




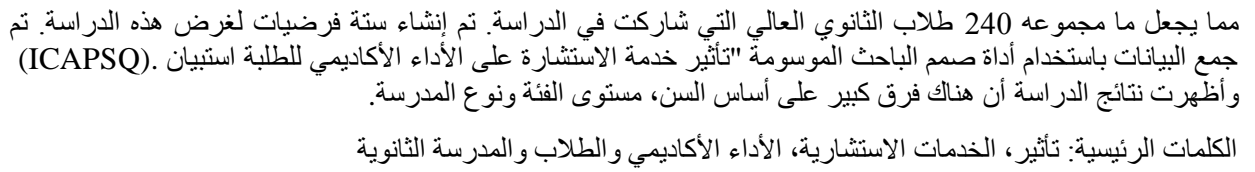

German Abstract

Einfluss von Beratungsdiensten auf die akademische Leistung von Sekundarschülern im Lagos-Staat

Diese Studie zielte darauf ab, den Einfluss von Beratungsdiensten auf die wahrgenommene akademische Leistung von Sekundarschülern in Lagos State zu betrachten. Im ersten Schritt wählten die Forscher gezielt Ikorodu L.G.A in Lagos State. In der zweiten Phase wählten die Forscher zwei Schulen (1 Privatschulen und 1 öffentliche Schulen) mit einfacher Zufallsmethode. So wurden insgesamt zwei Schulen in jedem der L.G.A. Schließlich wurde eine einfache zufällige Stichprobe bei der Auswahl von achtzig Studenten in jedem L.G.A verwendet, so dass insgesamt zweihundert und vierzig Senior Secondary Studenten, die an der Studie teilgenommen. Für diese Studie wurden sechs Hypothesen erzeugt. Daten wurden mit einem Forscher entworfen Instrument mit dem Tag "Einfluß des Beratungsdienstes auf akademische Leistung des StudentenFragebogens (ICAPSQ) gesammelt. Die Ergebnisse dieser Studie zeigten, dass es keinen signifikanten Unterschied auf der Grundlage von Alter, Klassen- und Schultyp gab.

Schlüsselwörter: einfluss, beratungsdienst, akademische leistung, studenten, weiterführende schule

\section{Malaysian Abstract \\ Pengaruh Perkhidmatan Kaunseling pada Prestasi Akademik Pelajar Sekolah Menengah di Lagos State}

Kajian ini bertujuan untuk melihat pengaruh perkhidmatan kaunseling kepada prestasi akademik dan tanggapan pelajar sekolah menengah di Lagos State. Pada peringkat pertama, penyelidik bertujuan dipilih Ikorodu L.G.A di Lagos State. Pada peringkat kedua, penyelidik memilih dua sekolah (1 Sekolah swasta, \& 1 Sekolah Awam), menggunakan teknik rawak mudah. Oleh itu, sebanyak dua buah sekolah telah dipilih dalam setiap L.G.A. yang Akhirnya, persampelan rawak mudah telah digunakan dalam memilih lapan puluh pelajar dalam setiap L.G.A, menjadikan sejumlah dua ratus empat puluh pelajar Senior menengah yang mengambil bahagian dalam kajian ini. Hipotesis telah dihasilkan untuk tujuan kajian ini. Data dikumpulkan dengan menggunakan instrumen penyelidik direka tagged "Pengaruh Counselling Service bagi Prestasi Akademik Pelajar Questionnaire (ICAPSQ). Hasil kajian ini menunjukkan bahawa terdapat perbezaan yang signifikan berdasarkan umur, tahap kelas dan jenis sekolah.

Kata Kunci: pengaruh, perkhidmatan kaunseling, prestasi akademik, pelajar, sekolah menengah 


\section{Russian Abstract \\ Влияние Консультационных Услуг на Академическую Успеваемость Учащихся Средних Школ в Штате Лагос}

Это исследование было нацелено на изучение влияния консультационных услуг на академическую успеваемость учащихся средних школ в штате Лагос. На первом этапе 2 из 3 исследователи целенаправленно выбрали Икороду Л.Г.А штате Лагос. На втором этапе исследователи выбрали две школы (1 частную школу и 1 государственную школу), использование простой случайной техники. Таким образом, в общей сложности две школы были отобраны в каждом из L.G.A. Наконец, при отборе 80 студентов в каждом L.G.A была использована простая случайная выборка, в результате чего в исследовании приняло участие двести сорок старших учащихся средних школ. Для этого исследования были подготовлены шесть гипотез. Данные были собраны с использованием разработанного исследователем инструмента с пометкой "Влияние Консультационной Службы на Академическое Выполнение Анкеты для Студентов” (ICAPSQ). Результаты этого исследования показали, что существенных различий по возрасту, классу и типу школы не выявлено.

Ключевые Слова: влияние, консультирование, успеваемость, учащиеся, средняя школа 